\title{
HOW EFFECTIVE IS THE STUDENT RESPONSE SYSTEM (SRS) IN FACILITATING STUDENT'S LEARNING
}

\author{
Yau Sui Yu and Wong Suet Lai \\ Open University of Hong Kong, Jubilee College, 81 Chung Hau St., Homantin, Hong Kong
}

\begin{abstract}
The prevalence of using educational technology in the $21^{\text {st }}$ century has been increasing as complementary research-informed teaching practices about learners's engagement, learning, and communication in learning transfer and retention (Berry, 2009; Bollmeier, Wenger, \& Forinash, 2010; Cole \& Kosc, 2010; Gauci, Dantas, Williams, \& Kemm, 2009; Medina et al., 2008; Patterson, Kilpatrick, \& Woebkenberg, 2010). However, the limited evidence of how educational technology of student response system (SRS) in facilitating student's learning in course-based higher education context and professional training, calls for an immediate need to examine the under-researched area.
\end{abstract}

\section{KEYWORDS}

Educational Technology, Student Response System

\section{INTRODUCTION}

The increased prevalence of using educational technology in the $21^{\text {st }}$ century requires complementary research-informed teaching practices about learners, learning, and communication regarding techniques can accelerate learning transfer and retention (Berry, 2009; Bollmeier et al., 2010; Cole \& Kosc, 2010; Gauci et al., 2009; Medina et al., 2008; Patterson et al., 2010). The purpose of this paper is to discuss the empirical evidence on how capable is educational technology like the student response system (SRS) to facilitate students' learning. This study will address the emerging need for research on SRS in facilitating student's learning in the course-based higher education context and professional training.

\section{CONTENT}

The term educational technology has evolved over the years reacting to the changes in emerging technologies, theories and practices of instructional technology for the facilitation of learning (Luppicini, 2005). The concept of educational technology has been interpreted and emphasised on various aspects including the use of theory and practices with the importance of resources. Professionals in the field have used the terms "Educational" and "Instructional" interchangeably throughout the years (Luppicini, 2005).

The use of educational technology to facilitate students' engagement and motivation in learning has led to developing a wide range of educational technologies, such as SRS, to foster knowledge application effectively in higher education training (Jones, Antonenkot, \& Greenwood, 2012; Lin, 2015; Robinson \& Dearmon, 2013). With the advancement of educational technology, SRS can be efficiently implemented with less hardware required concurrently.

Preis et al. (2011) revealed that SRS permits instructors to ask routine questions in large size classes, receive real-time responses from students, and provide immediate feedback to students. This advanced educational technology facilitates ubiquitous learning outcomes (Berry, 2009; Bollmeier et al., 2010; Cole \& Kosc, 2010; Gauci et al., 2009; Medina et al., 2008; Patterson et al., 2010). DeBourge (2008) had shifted the focus of lecture interaction from comprehension to higher cognition on application and analysis on the level of the questions being asked via SRS. Furthermore, the regular questioning as an instructional strategy for a large class size can prompt for further discussion, and promote preparation for class (Cain, Black, \& Rohr, 2009; DeBourgh, 2008; Hwang et al., 2015; Jones et al., 2012; Lin, 2015). Recently, Aljaloud and colleagues (2015) had focused on 
the historical background and provided a review on the pedagogical implications of SRS. The findings from the reviewed studies showed that SRS facilitated students' learning progress and motivated their engagement in lecture materials.

However, these studies drew upon the introduction of educational technologies at a convenient point during the (thereby enhanced) learning process, with a conclusion concerning the improvement. Given the limited views from literature, it was likely that the findings could reveal the facilitation only as regards some part of learning process, as opposed to a comprehensive improvement. The available studies are insufficient to explain how technology-enhanced learning can succeed in a course-based environment - in a comprehensive manner. The limited evidence of educational technology-enhanced learning in a course-based higher education context in previous studies calls for an immediate need to examine the perception of educational technology, in particular, SRS.

\section{CONCLUSION}

The reviewed studies have been embedded in online and face-to-face approaches. Therefore, when moving to the more dynamic tools available today such as SRS, the limited views from literature is unlikely that they could reveal an overall facilitation of learning, when one considers it comprehensively. This paper addresses the emerging need for research on how educational technology of SRS in facilitating student's learning in the course-based higher education context.

\section{ACKNOWLEDGEMENT}

The work described in this paper was fully supported by a grant from the Katie Shu Sui Pui Charitable Trust -Research and Publication Fund (KS 2018/1.1).

\section{REFERENCES}

Aljaloud, A., Gromik, N., Billingsley, W., \& Kwan, P. (2015). Research trends in student response systems: A literature review. International Journal of Learning Technology, 10(4), 313-325.

Berry, J. (2009). Technology support in nursing education: clickers in the classroom. Nursing Education Research, 30(5), 295-298.

Bollmeier, S. G., Wenger, P.J. \& Forinash, A. B. (2010). Impact of online lecture-capture on student outcomes in a therapeutics course. American Journal of Pharmaceutical Education, 74 (7), Article 127.

Cain, J., Black, E. P. \& Rohr, J. (2009). Instructional design and assessment: An Audience response system strategy to improve student motivation, attention, and feedback. American Journal of Pharmaceutical Education, 73 (2), Article 21.

DeBourgh, G. A. (2008). Use of classroom "clickers" to promote acquisition of advanced reasoning skills. Nurse Education in Practice, 8, 76-87. doi: 10.1016/j.nepr.2007.02.002

Gauci, S. A., Dantas, A.M., Williams, D. A., \& Kemm, R.E. (2009). Promoting student-centreed active learning in lectures with a personal response system. Advances in Physiology Education, 33 (1), 60 - 67.

Hwang, I., Wong, K., Lam, S. L. \& Lam, P. (2015). Student response (clicker) systems: Preferences of biomedical physiology students in Asian Classes. The Electronic Journal of e-Learning, 13 (5), 319-330.

Jones, M. E., Antonenkot, P. D. \& Greenwood, C. M. (2012). The impact of collaborative and individualized student response system strategies on learner motivation, metacognition, and knowledge transfer. Journal of Computer Assisted Learning, 28, 477-487. doi:10.1111/j.1365-2729.201100470.x

Lin, K. Y. (2015). Evaluating the effect of a clicker in an information literacy course for college nursing students in Taiwan. CIN: Computers, Informatics, Nursing, 33 (3), 115-121. doi:10.1097/CIN.0000000000000129

Luppicini, R. (2005). A systems definition of educational technology in society. Journal of Educational Technology \& Society, 8 (3), 103 -109. Retrieved from http://www.jstor.org/stable/jeductechsoci.8.3.103

Medina, M.S., Medina, P. J. Wanzer, D. S., Wilson, J.E., Er, N. \& Britton, M. L. (2008). Use of an audience response system (ARS) in a dual-campus classroom environment. American Journal of Pharmaceutical Education, 72 (2), Article 38.

Patterson, B., Kilpatrick, J., Woebkenberg, E. (2010). Evidence for teaching practice: The impact of clickers in a large classroom environment. Nurse Education Today, 30 (7), 603 - 607. 